\title{
Influence of external pH on ciliary beat frequency in human bronchi and bronchioles
}

\author{
C. Clary-Meinesz*, J. Mouroux+, J. Cosson++, P. Huitorel++, B. Blaive*
}

Influence of external $\mathrm{pH}$ on ciliary beat frequency in human bronchi and bronchioles. $C$. Clary-Meinesz, J. Mouroux, J. Cosson, P. Huitorel, B. Blaive. OERS Journals Ltd 1998.

ABSTRACT: Ciliated respiratory epithelial cells have to tolerate variations in local pH caused by the respiratory cycle and potential ventilation-perfusion mismatches. We showed previously that peripheral bronchiolar cilia beat at a lower frequency than bronchial cilia, and have now investigated whether they show differences in tolerance to changes in $\mathrm{pH}$.

Using the image analysis system applied in the previous study, we compared variations in the ciliary beat frequencies (CBF) of bronchi and bronchioles sampled from human lung resections at various $\mathrm{pH}$ in vitro.

Application of nonparametric tests (the variance of samples was not similar) indicated that CBF was not significantly modified when $\mathrm{pH}$ was varied between 7.5 and $\mathbf{1 0 . 5}$ for bronchi, and between 5.5 and $\mathbf{1 0 . 5}$ for bronchioles. Reversible and significantly lower CBF were observed below pH 7.0 for bronchi and below pH 5.0 for bronchioles. Extreme pH values such as 11.0 or 3.0 were lethal within a few minutes.

Thus, respiratory ciliary beating is able to tolerate external $\mathrm{pH}$ variations between 3.5 and 10.5 without permanent impairment. In addition we found that alkaline $\mathrm{pH}$ values are more favourable than acidic ones and that bronchiolar ciliated cells are more tolerant to acidic pH than bronchial cells. Eur Respir J 1998; 11: 330-333.
* Service de Pneumologie, and +Chirurgie Thoracique, Hôpital Pasteur, Pavillon $\mathrm{H}$ Nice, France. +URA 671 CNRS Observatoire Océanologique, Villefranche-sur-Mer, France.

Correspondence: C. Clary-Meinesz

Service de Pneumologie

Hôpital Pasteur- Pav. H

B.P. 69

F - 06002 Nice cedex 1

France

Fax: 33492038018

Keywords: Ciliary beat frequency, environment, human, mucociliary, $\mathrm{pH}$, physiology

Received: June 41997

Accepted after revision October 211997

This study was supported by grants from the Centre National de la Recherche Scientifique (CNRS) (J.C. and P.H.) and the Société d'Etudes et de Recherches PneumoPhtisiologiques de la Côte d'Azur (SREPPCA) (C.M.C, J.M. and B.B.).
Most studies concerning the importance of the $\mathrm{pH}$ for ciliary activity have been performed on marine invertebrates and protists [1]. In these organisms, ciliary beating appears adapted to the characteristic and stable $\mathrm{pH}$ of the environment. On the other hand, ciliated respiratory epithelial cells are exposed to $\mathrm{pH}$ variations due to the respiratory cycle [2]. In humans, normal $\mathrm{pH}$ values in tracheal mucus range 6.9-9.0 [3]. Moreover, infection can be accompanied by $\mathrm{pH}$ values as low as $\mathrm{pH} 5.8$ in mucus [4]. How can ciliary movement cope with such variations in external $\mathrm{pH}$ ? A previous study showed that nasal ciliated cells may resist $\mathrm{pH}$ variations between 7 and 9 [5]. The buffering capacity of bronchial secretions (periciliary fluid and mucus) is lower than in plasma, varies from day to day and individually, and $\mathrm{pH}$ variations may be encountered upon exposure to acidic compounds [6]. Variations in capnia induce modifications in carbonic acid concentrations of the periciliary fluid leading to $\mathrm{pH}$ variations [7]. Local perfusion-ventilation mismatches may enhance this phenomenon.

In a previous work [8], we showed that the ciliary beat frequencies (CBFs) of peripheral bronchioles are significantly lower than those of proximal bronchi (4.6 versus $7.1 \mathrm{~Hz}$, respectively), which may explain the low mucociliary clearance observed in peripheral regions of the lung. Here we examine CBF modifications induced by $\mathrm{pH}$ variations in the medium surrounding ciliated cells and compare results from bronchi and bronchioles.
Materials and methods

\section{Preparation of ciliated cells}

Measurements were made from 17 lungs resected for tumours. Patients with preoperative treatments such as irradiation or chemotherapy were excluded. Operative procedure and general anaesthesia were similar for all patients.

Characteristics of the patients are not given as we, and others, have shown that there is no significant difference in CBF with sex, age or lung function, or with smoking status [5, 8]. Lung tissues were examined for sampling within $1 \mathrm{~h}$ of resection. Specimens showing purulent discharges from airways were excluded. Proximal brushings were immediately performed on normal areas of the resected cartilaginous bronchus; after dissection of a small bronchus, distal brushings were performed by brushing the surface of bronchioles less than $2 \mathrm{~mm}$ in diameter, longitudinally opened, and by pushing the disposable cytology brush, one millimetre in diameter, through a small bronchiole of a diameter slightly superior to that of the brush, close to the visceral pleura. Specimens were dislodged from the brush by shaking it in RPMI 1640 medium supplemented with colistine (100 IU.mL-1) and penicillin (100 $\left.\mathrm{IU} \cdot \mathrm{mL}^{-1}\right)$. The samples were kept at $4^{\circ} \mathrm{C}$ until measurements, which were performed within $24 \mathrm{~h}$. Samples with 
numerous normal beating ciliated cells were kept for experiments. All experiments, including CBF measurements, were performed at room temperature, constantly maintained through air-conditioning. A temperature of $22^{\circ} \mathrm{C}$ was chosen to minimize air drying, bacterial growth and deleterious effects. The study was approved by the local institutional ethics commission.

\section{Experimental design}

Cells were kept in RPMI 1640 supplemented with penicillin $\left(100 \mathrm{IU} \cdot \mathrm{mL}^{-1}\right)$ and colistine $\left(100 \mathrm{IU} \cdot \mathrm{mL}^{-1}\right)$ at $4^{\circ} \mathrm{C}$, which allows $\mathrm{CBF}$ s of specimens to remain stable for 2-3 days, in our experience. All CBF measurements were made within $24 \mathrm{~h}$ and at room temperature $\left(22^{\circ} \mathrm{C}\right)$. All distal samplings came from bronchioles of less than $2 \mathrm{~mm}$ in diameter. Measurements were made on small groups of ciliated cells, single cells being discarded as their CBFs are usually lower and variable. The CBFs of at least ten different cells were measured for each specimen. The initial $\mathrm{pH}$ of the medium was 7.2. A series of incubation media were made by adjusting the primary medium (RPMI 1640 which included N-2-hydroxyethylpiperazine-N-2ethane sulphonic acid (HEPES) and glutamine) to $\mathrm{pH}$ ranging 3-11 with $0.1-1 \% \mathrm{v} / \mathrm{v}$ of $0.3 \mathrm{~N} \mathrm{HCl}$ or $0.3 \mathrm{~N} \mathrm{NaOH}$. Ionic concentrations varied by not more than $1 \%$, and osmolarity was, thus, considered stable. The sodium concentration in the medium was $100 \mathrm{mM}$, which is in the recommended range [5]. Large variations in osmolarity of the medium do not induce significant $\mathrm{CBF}$ changes between 300 and $450 \mathrm{mOs}$ [9] or 150 and $600 \mathrm{mOs}$ [10].

Fifty microlitres of cell suspension were added to $5 \mathrm{~mL}$ of incubation medium at the chosen $\mathrm{pH}$. The $\mathrm{pH}$ of the resulting incubation medium was measured using a digital pH-meter (Mini 80; Tacussel, Villeurbanne, France) with a precision of $0.01 \mathrm{pH}$ units, and gave the value of incubation $\mathrm{pH}$. Before each measurement, the $\mathrm{pH}$ meter was calibrated using reference buffers. After a 5 min incubation period we sampled $100 \mu \mathrm{L}$ to measure CBF. Reversibility was checked after a second incubation period of $5 \mathrm{~min}$ at $\mathrm{pH} 7$, adding $0.3 \mathrm{~N} \mathrm{HC1}$ or $0.3 \mathrm{~N} \mathrm{NaOH}$, less than $1 \%$ of total volume of incubation medium. Ionic strength and temperature were maintained constant.

\section{Recording of ciliary beat frequency}

A small volume of cell suspension was placed between a slide and a coverslip, and ciliated cells were examined with a negative phase contrast microscope (Optiphot 2; Nikon Corporation, Tokyo, Japan) using a $40 \times 10 \mathrm{mag}-$ nification. To minimize the influence of the microscope lamp on the temperature of the cell suspension, a caloric filter was used and CBF measurements were always made within $5 \mathrm{~min}$ for each experiment, so that temperature modifications were kept to a minimum and were similar in all experiments.

Images were scanned by a video camera (Panasonic CCD F15; Matsushita Electric Industrial Co., Osaka, Japan) and stored on a video tape recorder (Panasonic S-VHS 7530; Matsushita Electric Industrial Co.). Images were displayed onto a video monitor. We selected the edge of the cell where ciliary beat was observed distinctly, and at least 10 different areas were selected from each sample. Video sequences were analysed by an image analysis system, as described previously [11]. Briefly, each image was normalized by a digital time base corrector system (TBC FA300P; For A Company Ltd, Tokyo, Japan). The video signal was digitized by an image processing card (PIP 1024B; Matrox Electronic System Ltd, Dorval, PQ, Canada) implanted in a PC AT/386 microcomputer (SOS Informatique, Nice, France). Each frame was digitized into $512 \times$ 512 pixels with 256 grey level values. One hundred and twenty eight images were analysed over a $5 \mathrm{~s}$ period and statistical analyses were performed using the Stat 2005 program (Alcatel TITN, Alcatel Alsthom, Paris, France). Average optical density measurements allowed us to obtain optical density variations as a function of time for each selected area. Beat frequencies were obtained from K covariances of the optical density as a function of time.

\section{Statistical analysis}

Results are expressed as mean with one standard error of the mean (SEM). Each CBF value is the average of at least 10 different measurements, mostly 40. Each data point presented in the measurement of reversibility of $\mathrm{pH}$ induced CBF modifications represents the average of three or more experiments performed on different explants. Each $\mathrm{pH}$ group (e.g. 3, 3.5, 4, 4.5, etc) was measured at the corresponding $\mathrm{pH}$ value plus or minus 0.2 units (e.g. " $\mathrm{pH} 7$ " values were between 6.8 and 7.2). CBF measurements at pH 3 and pH 11 which approached zero, were significantly different. We compared results from bronchi or bronchioles at $\mathrm{pH}$ values ranging 3.5-10.5, using nonparametric tests, as variance was different in some experiments. According to the Kruskall-Wallis test, all measurements were grouped in one population, ordered from the smallest to the biggest value with a serial number, taking into account similar values. Heterogeneity was significantly demonstrated $(\mathrm{p}<0.005)$ from the calculation of the auxiliary variable of Kruskall Wallis test (Hc) [12]. The samples were compared according to a multiple comparison test [13]. Briefly the ZHjl of the distribution of each sample was compared to $\mathrm{Za}^{\prime}$ of the normal law, which must lie above 3.5 for bronchi $\left(a^{\prime}=2 \times 10^{-4}\right)$, and above 3.4 for bronchioles $\left(a^{\prime}=3 \times 10^{-4}\right)$, to indicate a significant difference $(\mathrm{p}<0.05)$.

\section{Results}

The influence of the $\mathrm{pH}$ in the medium on $\mathrm{CBF}$ is shown in table 1 and figures 1 and 2. CBF modifications were induced by incubating ciliated respiratory cells in culture medium at different $\mathrm{pH}$ values and the reversibility of those effects was subsequently monitored (fig. 2).

$\mathrm{CBF}$ of bronchial cells remained stable between $\mathrm{pH} 7.5$ and $10.5(\mathrm{ZHjl}<3.5)$. When the $\mathrm{pH}$ value was lowered below $\mathrm{pH} 7.0, \mathrm{CBF}$ decreased significantly. CBF values at $\mathrm{pH} 7.5$ differed significantly from CBF values at $\mathrm{pH} 7.0$, but the level of significance was not high $(\mathrm{ZHjl}=4$, compared to 3.5). A pH value of 5.5 reduced the bronchial CBF by $50 \%$, while ciliary activity was almost arrested at $\mathrm{pH} 3.5$. At $\mathrm{pH} 3.0$ or 11.0 cells were irreversibly damaged: at $\mathrm{pH} 11.0$, cells were progressively damaged, allowing some initial CBF measurements within the first $5 \mathrm{~min}$, whereas at $\mathrm{pH} 3.0$ they showed deleterious effects too fast to allow any CBF measurement (fig. 1a). 
Table 1. - Bronchial and bronchiolar mean ciliary beat frequency (CBF) obtained after incubation for $5 \mathrm{~min}$ at various $\mathrm{pH}$ of the ratio of the obtained $\mathrm{CBF}$ to the initial $\mathrm{CBF}(\mathrm{CBF})$ measured at $\mathrm{pH} 7.2$

\begin{tabular}{|c|c|c|c|c|c|c|}
\hline \multicolumn{4}{|c|}{ Bronchi } & \multicolumn{3}{|c|}{ Bronchioles } \\
\hline $\mathrm{pH}$ & $\begin{array}{l}\mathrm{CBF} \\
\mathrm{Hz}\end{array}$ & SEM & $\begin{array}{c}\mathrm{CBF} / \mathrm{CBFi} \\
\%\end{array}$ & $\begin{array}{l}\mathrm{CBF} \\
\mathrm{Hz}\end{array}$ & SEM & $\begin{array}{c}\mathrm{CBF} / \mathrm{CBFi} \\
\%\end{array}$ \\
\hline 3.0 & $0.00 *$ & 0.00 & 0 & $0.05 *$ & 0.00 & 0 \\
\hline 3.5 & 1.54 & 0.23 & 23 & 1.61 & 0.14 & 57 \\
\hline 4.0 & 3.69 & 0.23 & 58 & 2.47 & 0.18 & 72 \\
\hline 4.5 & 2.58 & 0.11 & 42 & 2.44 & 0.12 & 64 \\
\hline 5.0 & 3.13 & 0.12 & 51 & 2.18 & 0.09 & 61 \\
\hline 5.5 & 3.33 & 0.53 & 47 & 2.51 & 0.14 & 70 \\
\hline 6.0 & 3.73 & 0.19 & 61 & 2.84 & 0.08 & 86 \\
\hline 6.5 & 4.69 & 0.11 & 78 & 2.71 & 0.09 & 84 \\
\hline 7.0 & 6.29 & 0.09 & 100 & 3.73 & 0.11 & 100 \\
\hline 7.5 & 5.96 & 0.79 & 95 & 3.41 & 0.08 & 96 \\
\hline 8.0 & 5.37 & 0.17 & 91 & 3.77 & 0.11 & 108 \\
\hline 8.5 & 5.20 & 0.27 & 92 & 3.70 & 0.13 & 107 \\
\hline 9.0 & 6.33 & 0.25 & 91 & 3.95 & 0.18 & 109 \\
\hline 9.5 & 6.06 & 0.09 & 102 & 4.08 & 0.13 & 111 \\
\hline 10.0 & 6.79 & 0.26 & 104 & 4.96 & 0.18 & 107 \\
\hline 10.5 & 5.01 & 0.22 & 89 & 3.93 & 0.18 & 106 \\
\hline 11.0 & $4.11 *$ & 0.42 & 64 & $2.14 *$ & 0.30 & 75 \\
\hline
\end{tabular}

*: extreme pHs 3.0 and 11.0 induced irreversible instability of CBF.
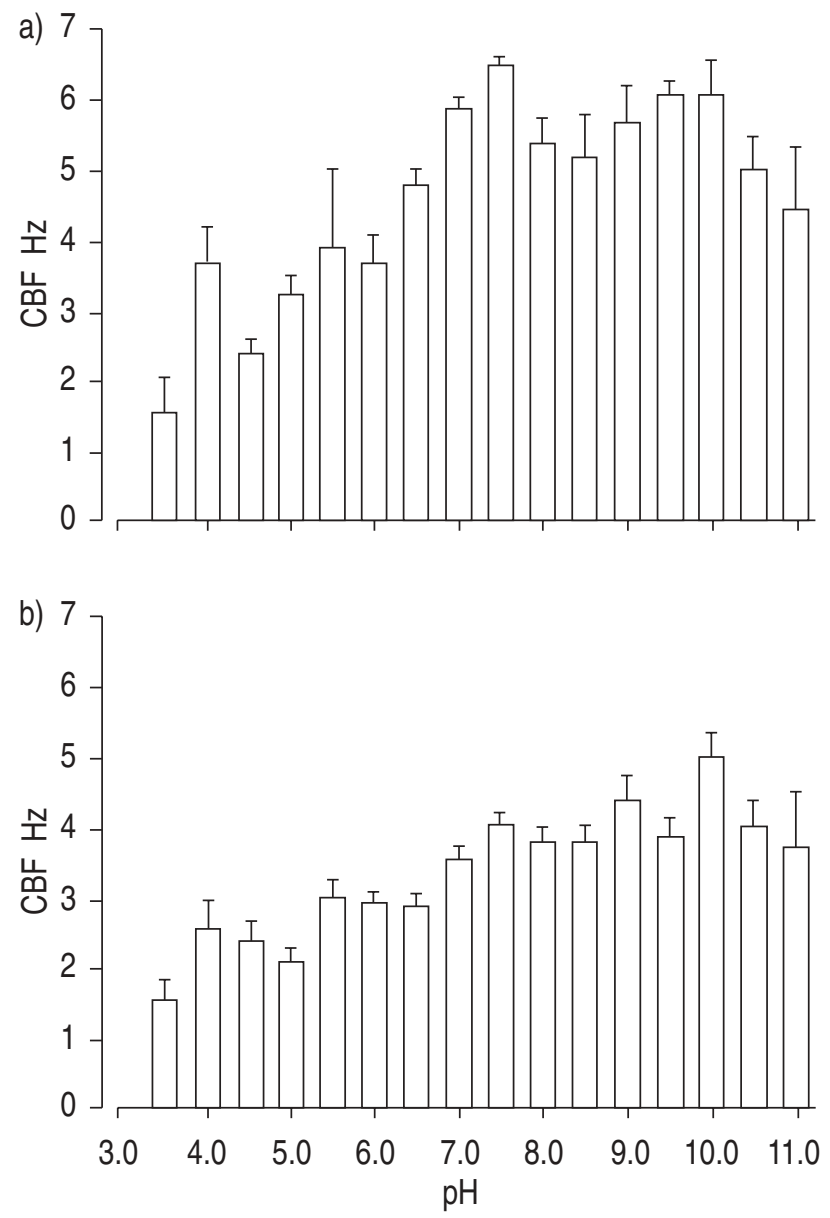

Fig. 1. - a) Bronchial and b) bronchilar ciliary beat frequencies $(\mathrm{CBF})$ according to external $\mathrm{pH}$ values, within $5 \mathrm{~min}$ of incubation (extreme $\mathrm{pHs}, 3.0$ and 11.0, induce irreversible instability of CBF). Results are presented as mean and $95 \%$ confidence intervals.

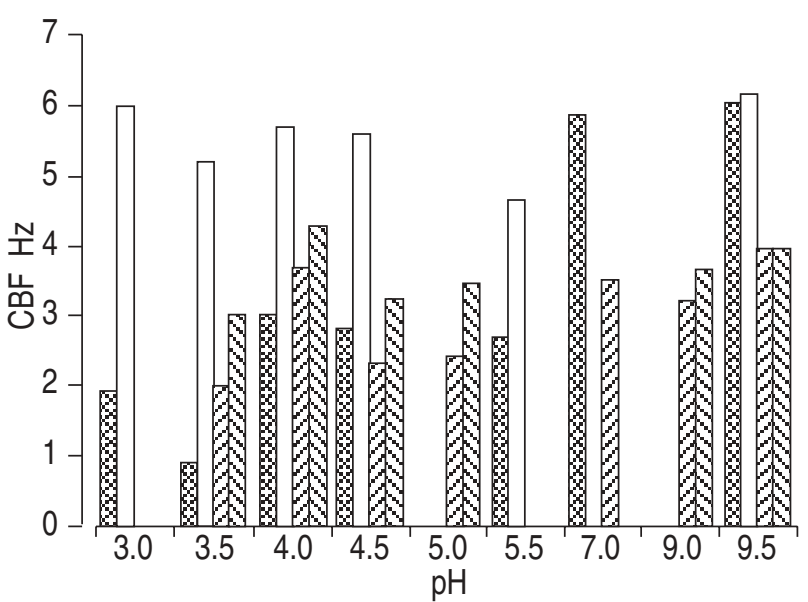

Fig. 2. - Reversibility of the pH-induced ciliary beat frequency $(\mathrm{CBF})$ modifications. Pooled mean bronchial and bronchiolar $\mathrm{CBF}$ at $\mathrm{pH} 7.0$ are given for comparison. $\$$ : bronchi; $\square$ : bronchi at $\mathrm{pH} 7 ; \measuredangle$ bronchioles; $Z 2$ : bronchioles at $\mathrm{pH} 7$.

Bronchiolar ciliary beat behaviour was slightly different. Bronchiolar CBF did not differ significantly from initial values at $\mathrm{pH} 7.0$ between $\mathrm{pH} 5.5$ and $10.5(\mathrm{ZHjl}<3.4)$. In contrast to bronchial cilia there was no difference between $\mathrm{CBF}$ at $\mathrm{pH} 7.0$ and $\mathrm{pH}$ 7.5. Below $\mathrm{pH} 3.5$, CBF decreased by more than $50 \%$. As seen for bronchial cells, $\mathrm{pH}$ 3.0 and 11.0 were deleterious in the same way (fig. 1b).

The reversibility of the $\mathrm{pH}$ induced CBF modification was tested. Figure 2 shows examples of these CBF modifications which were reversible when cells were brought back to $\mathrm{pH}$ 7. We gave particular attention to acidic $\mathrm{pH}$ values, where a $\mathrm{pH}$ such as 3.5 induced $50 \% \mathrm{CBF}$ decrease that was totally reversible within $5 \mathrm{~min}$ at $\mathrm{pH} 7.0$.

\section{Discussion}

In our experimental conditions, we showed that bronchial CBF does not significantly change in response to changes in the $\mathrm{pH}$ of the external medium between 7.5 and 10.5. CBF values obtained at $\mathrm{pH} 7.0$ compared to 7.5 did, however, show a slight but significant difference. LuK and Dulfano [5], found a stable nasal CBF between $\mathrm{pH} 7.0$ and 9.0. IngeLs et al. [9], demonstrated that nasal CBFs in humans do not change when $\mathrm{pH}$ varies from 6.5 to 7.5. These observations suggest that nasal and large airway ciliated cells are similar concerning their tolerance to alterations of $\mathrm{pH}$.

With bronchiolar ciliated cells, we showed that they maintain their normal CBF within a limit of $\mathrm{pH}$ 5.5-10.5. CBFs of bronchiolar cells appear more tolerant to acidic $\mathrm{pH}$ than bronchial cells (5.5 versus 7.5 ).

In other animals, a variety of $\mathrm{pH}$-induced modifications of CBF have been reported, but all studies confirm the high resistance of respiratory ciliated cells to large variations in $\mathrm{pH}$. In rats, tracheal $\mathrm{CBF}$ is significantly inhibited by $\mathrm{pH}$ below 6 and accelerated by $\mathrm{pH}$ between 9 and 11 [10]. In chicken embryos, as well as in rats, VAN DE DoNK et al. [14], found a stable tracheal $\mathrm{CBF}$ at $\mathrm{pH}$ values ranging 7-10, with a slight initial acceleration at $\mathrm{pH} 10$. Cilia in- tegrity is preserved if $\mathrm{pH}$ variations are restricted to values ranging 6.5-8.5 [15]. In cows, no histopathological changes or dysfunctions are observed in cilia in the $\mathrm{pH}$ range 
6.7-9.5 [16]. These differences in threshold $\mathrm{pH}$ values may represent variations due to the method for measuring $\mathrm{pH}$ more than species characteristics.

Normal values, measured in situ, are around $\mathrm{pH} 6.7$ in rabbit airways [2]. In rats the $\mathrm{pH}$ of tracheal mucus ranges 7.4-7.6 [17]. In humans, tracheal $\mathrm{pH}$ values of mucus range 6.9-9.0 [3]. However, in pathological conditions, acidification of the bronchial mucus has been recorded, for instance during metabolic or respiratory acidosis [7], diabetes mellitus [18] and bacterial pneumonia [3]. The $\mathrm{pH}$ does not, however, change significantly during simple bacterial colonization (bacterial colonization without pneumonia) [3]. Taken together, these observations suggest that the impairment of $\mathrm{CBF}$ at acidic $\mathrm{pH}$ may play a part in the development of pneumonia, together with the increased viscosity of the mucus, which impairs the mucociliary clearance even further [6].

Variations in $\mathrm{pH}$ values in the range 6.4-7.8 have been reported in mucus due to changes in carbon dioxide concentration with the respiratory cycle [19], or to the secretions of bicarbonate or hydrogen ions by the epithelial cells [20]. As for airway surface liquid, comprising periciliary fluid and mucus, the $\mathrm{pH}$ is slightly acidic compared to plasma: about 7 in ferrets [20] and 6.8 in humans [21]. It may vary from 6.85 to 6.92 following variation in carbon dioxide concentration in ferret [22]. These variations should not impair the transport of mucus, according to our experimental results. In addition bronchiolar cilia appear resistant to acidic $\mathrm{pH}$ values over a greater range than bronchial cilia. As far as we know, no direct $\mathrm{pH}$ measurement of the airway surface liquid in the distal part of the airways has been performed. GuERRI et al.[2] found slight-ly lower in situ $\mathrm{pH}$ values in the main stem bronchus than in the trachea of rabbits. We may expect larger variations in carbon dioxide concentration at the bronchiolar level compared to the large airways according to the ventilation- perfusion ratio and, thus, larger external variations of $\mathrm{pH}$. From our results, $\mathrm{CBF}$ is unlikely to be impaired in the $\mathrm{pH}$ range found along the respiratory tract. Respiratory cilia are, thus, adapted to the characteristics of $\mathrm{pH}$ encountered in their environment.

In experimental conditions however, $\mathrm{pH}$ should always be checked and specified, as ciliary modifications may be explained or even enhanced by $\mathrm{pH}$ modifications [23, 24]. As we show the stability of ciliary beat with alkaline external $\mathrm{pH}$, we suggest the use of buffered solutions with a $\mathrm{pH}$ value of around 8.5 for medications to be administrated by aerosol so that clearance of mucus is made easier, especially when bacterial infections may have already lowered the $\mathrm{pH}$, inducing suboptimal values of CBF.

In conclusion ciliary beating of human respiratory ciliated cells tolerates external $\mathrm{pH}$ variations over a wide range, and bronchiolar cells, which beat slower than bronchial cells, are even more tolerant: ciliary beat frequency is stable between pH 5.5 and 10.5 for bronchiolar cells and between $\mathrm{pH} 7.5$ and 10.5 for bronchial cells. This tolerance seems to be adapted to the true variations of $\mathrm{pH}$ in the airway surface liquid observed with respiratory cycle and level of ventilation.

Acknowledgements: The authors are grateful to E. Houliston for correcting the English text, to R. Lemée for help in the statistical analysis and to D. Schoevaert for advice during the progress of this work.

\section{References}

1. Gray J. The mechanism of ciliary movement. Proc $R$ Soc (B) 1922; 93: 122-131.

2. Guerrin F, Robin H, Lequien $\mathrm{P}$, Lambert P. pH métric bronchique in situ. J Physiol Paris 1970; 62 (S2): 282.

3. Karnad DR, Mhaisekar DG, Moralwar KV. Respiratory mucus $\mathrm{pH}$ in tracheostomized intensive care unit patients: effects of colonization and pneumonia. Crit Care Med 1990; 18: 699-701.

4. Buhrmester CC. A study of the hydrogen-ion concentration, nitrogen content and viscosity of nasal secretions. Ann Otol Rhinol Laryngol 1933; 42: 778-788.

5. Luk CK, Dulfano MJ. Effect of $\mathrm{pH}$, viscosity and ionicstrength changes on ciliary beat frequency of human bronchial explants. Clin Sci 1983; 64: 449-451.

6. Holma B. Influence of buffer capacity and $\mathrm{pH}$-dependent rheological properties of respiratory mucus on health effects due to acidic pollution. Sci Total Environ 1985; 41: 101-123.

7. Guerrin F, Robin H, Lambert P, Kine A. pH métric bronchique in situ. Effets de l'hypoxiehypercapnie. J Physiol Paris 1989; 61: 305-306.

8. Clary-Meinesz C, Mouroux J, Huitorel P, Cosson J, Blaive B. Ciliary beat frequency in human bronchi and bronchioles. Chest 1997; 111; 692-697.

9. Ingels KJAO, Kortmann MJW, Nijziel MR, Graamans K, Huizing EH. Factors influencing ciliary beat measurements. Rhinology 1991; 29: 17-26.

10. Hée J, Guillerm R. Influence des facteurs de l'environnement sur l'activité ciliaire et le transport du mucus. Bull Physiopathol Resp 1973; 2: 377-395.

11. Nasr G, Schoevaert D, Marano F. Progress in the measurement of ciliary beat frequency by automated image analysis: application to mammalian tracheal epithelium. Anal Cell Pathol 1995; 9: 165-177.

12. Scherrer B. Tests non paramétriques de comparaison dechantillon. In: Biostatistique. Montreal. Gaëtan Morin, 1984; pp. 182-186.

13. Noether GE. Introduction to statistics. A non parametric approach. 2nd edition, Boston, Houghton Mifflin Co., 1976.

14. Van de Donk HJM, Zuidema J, Merkus FWHM. The influence of the $\mathrm{pH}$ and osmotic pressure upon tracheal ciliary beat frequency as determined with a new photo-electric registration device. Rhinology 1980; 18: 93-104.

15. Su XY, Li Wan Po A. Surface-response study of the effect of $\mathrm{pH}$ and tonicity on ciliary activity. STP Pharma Sci 1994; 4: 82-85.

16. Holma B, Lindegren M, Andersen JM. pH effects on ciliomotility and morphology of respiratory mucosa. Arch Environ Health 1977; 32: 216-226.

17. Gatto LA. pH of mucus in rat trachea. J Appl Physiol 1981; 50: 1224-1226.

18. Yue WL. Nasal mucociliary clearance in patients with diabetes mellitus. J Laryngol Otol 1989; 103: 853-855.

19. Breuninger H. Uber das physikalisch-chemische Verhalten des Nasenschleims. Arch Ohr Nas Kehlkopfheilk 1964; 184: 133-138.

20. Widdicombe JG. Airway mucus. Eur Respir J 1989; 2: 107-115.

21. Boucher RC, Stutts MJ, Bromberg PA, Gatzy JT. Regional differences in airway surface liquid composition. J Appl Physiol 1981; 50: 613-620.

22. Kyle H, Ward JP, Widdicombe M. Control of $\mathrm{pH}$ of airway surface liquid of the ferret trachea in vitro. J Appl Physiol 1990; 68: 135-140.

23. Kienast K, Riechelmann H, Knorst M, et al. An experimental model for the exposure of human ciliated cells to sulfur dioxide at different concentrations. Clin Invest 1994; 72: 215-219.

24. Van de Donk HJM, Van Egmond ALM, Van den Heuvel AGM, Zuidema J, Merkus FWHM. The effects of drugs on ciliary motility. Local anaesthetics and anti-allergic drugs. Int J Pharm 1982; 12: 77-85. 